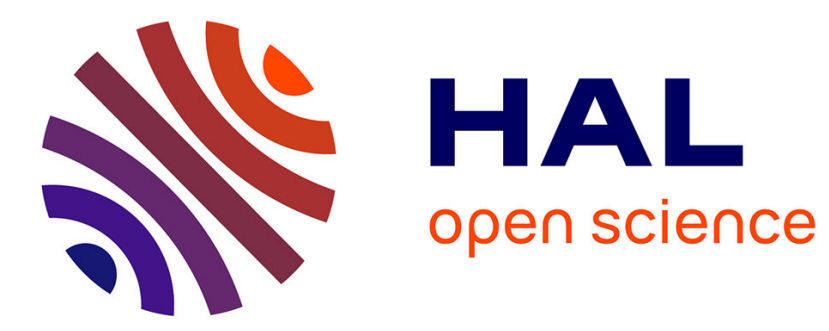

\title{
Electrodeposition and characterization of Silane thin films from 3-(aminopropyl)triethoxysilane
}

\author{
G. Herlem, Olivier Segut, A. Antoniou, C. Achilleos, Didier Dupont, V. \\ Blondeau-Patissier, T. Gharbi
}

\section{- To cite this version:}

G. Herlem, Olivier Segut, A. Antoniou, C. Achilleos, Didier Dupont, et al.. Electrodeposition and characterization of Silane thin films from 3-(aminopropyl)triethoxysilane. Surface and Coatings Technology, 2008, 202 (8), pp.1437-1442. 10.1016/j.surfcoat.2007.06.038 . hal-00493842

\section{HAL Id: hal-00493842 \\ https://hal.science/hal-00493842}

Submitted on 22 Apr 2021

HAL is a multi-disciplinary open access archive for the deposit and dissemination of scientific research documents, whether they are published or not. The documents may come from teaching and research institutions in France or abroad, or from public or private research centers.
L'archive ouverte pluridisciplinaire HAL, est destinée au dépôt et à la diffusion de documents scientifiques de niveau recherche, publiés ou non, émanant des établissements d'enseignement et de recherche français ou étrangers, des laboratoires publics ou privés.

\section{(c)(1)}

Distributed under a Creative Commons Attribution| 4.0 International License 


\title{
Electrodeposition and characterization of silane thin films from 3-(aminopropyl)triethoxysilane
}

\author{
Guillaume Herlem $^{\mathrm{a}, *}$, Olivier Segut ${ }^{\mathrm{a}}$, Alexandros Antoniou ${ }^{\mathrm{a}}$, Christine Achilleos ${ }^{\mathrm{b}}$, \\ Didier Dupont $^{\mathrm{b}}$, Virginie Blondeau-Patissier ${ }^{\mathrm{c}}$, Tijani Gharbi ${ }^{\mathrm{d}}$ \\ a Institut UTINAM UMR CNRS 6213, Bât. N, Université de Franche-Comté, UFR Sciences and Techniques, 16 route de Gray, 25030 BESANCON CEDEX, France \\ ${ }^{\mathrm{b}}$ URTAL, INRA, B.P. 20089, 39801 POLIGNY CEDEX, France \\ ${ }^{\mathrm{c}}$ Femto-ST/LPMO CNRS UMR 6174, 25030 BESANCON CEDEX, France \\ d Femto-ST/LOPMD CNRS UMR 6174, 25030 BESANCON CEDEX, France
}

\begin{abstract}
3-(aminopropyl)triethoxysilane based films have been electrodeposited directly on polycrystalline gold and gold (111) electrodes in aqueous 3-(aminopropyl)triethoxysilane based electrolyte and in tetrahydrofurane based electrolyte. These films were characterized by means of IR-ATR and X-ray photoelectron spectroscopies. The film morphology was investigated by scanning tunneling microscopy while the film growth was observed by ellipsometry measurements. The vibrationnal and X-ray photoelectron analysis suggest that the chemical composition of the electrodeposited films either in liquid tetrahydrofurane or in liquid 3-(aminopropyl)triethoxysilane is identical. The resulting coating thickness is different for the same biasing time in the two liquid media. The gold surface is coated irreversibly by an amino terminated film of great interest for sensor applications which was used as the functionalized part of a surface plasmon resonance biosensor to monitor $\alpha$-lactalbumin graft.
\end{abstract}

Keywords: Electrodeposition; 3-(aminopropyl)triethoxysilane; Scanning tunneling microscopy; Ellipsometry; X-ray photoelectron spectroscopy; Surface plasmon resonance

\section{Introduction}

As an alternative to sol-gel method, there were some reports of the electrochemical reduction of silanes yielding linear $\mathrm{Si}$ backbone polymers [1,2]. Recently, the electrodeposition of trimethoxysilane (TMOS) on negative biased conducting electrode surfaces to form thin silane films was also reported [3]. The deposition process of TMOS in aqueous solution is induced by the electrochemical reduction of oxygen to hydroxyl ions which acts as the catalyst for the hydrolysis and condensation of TMOS on the surface electrode.

\footnotetext{
* Corresponding author.

E-mail address: guillaume.herlem@univ-fcomte.fr (G. Herlem).
}

A few years ago, we have discovered a new way to electrosynthesize thin linear polypropylenimine films on gold electrodes by anodic oxidation of pure 1,3-diaminopropane [4-6]. Our aim is to diversify the way to graft amine based molecule on conducting surfaces and if possible using a molecule which plays at the same time the part of solvent and monomer (to electropolymerize). This is the reason why we used 3-(aminopropyl)triethoxysilane (3-APTES) monomer, a liquid in standard conditions, which contains both amino and silano groups. In this connection, we transposed the work made with TMOS with 3-APTES so that the gold electrode presents amino terminated groups on its surface and makes it possible to graft biological species.

Effectively, two recent papers reported the electrodeposition of 3-APTES on gold or on recordable gold-type compact disks but first modified with a monolayer of alkanedithiol $[7,8]$. Here 
we used the electrochemical generation of the condensation catalyst $[9,10]$ and applied it to 3 -APTES.

\section{Experimental}

All products were from Sigma-Aldrich (France) and ultra pure water (Milli-Q, Millipore) was used when needed. Bovine $\alpha$-lactalbumin was solubilized at $2 \mathrm{mg} / \mathrm{mL}$ in distilled water and stored at $-20{ }^{\circ} \mathrm{C}$. A standard three-electrode electrochemical cell setup was used and all potentials are quoted vs. a silver wire reference electrode (SRE).

Several gold substrates have been used in this study as working electrodes. $5 \mathrm{MHz}$ polished gold coated AT cut quartz (Maxtek, USA) was used (in shear mode) and mounted on a probe for electrochemical quartz crystal microbalance (EQCM) experiments $\left(1.37 \mathrm{~cm}^{2}\right.$ surface area). For scanning tunnel microscopy (STM) imaging, gold coated mica surface (Molecular Imaging, USA) with 1500 of Au (111) was used. $50 \mathrm{~nm}$ thickness gold on glass $\left(10 \times 12 \mathrm{~mm}^{2}\right.$ surface area) was used for surface plasmon resonance (SPR) measurements (Au Kit, Biacore).

Functional group analyses were carried out by means of the Omnisampler IR-ATR module plugged to the FT-IR spectrometer (Nexus 470; ThermoElectron, France).

Ellipsometric measurements were performed via an UVISEL (Horiba, France) phase-modulated spectroscopic ellipsometer. The incident angle was set at $70^{\circ}$ and the light spot was $1 \mathrm{~mm}$ in diameter. The measurements were performed in the spectral range $250-850 \mathrm{~nm}$, with sampling steps of $5 \mathrm{~nm}$.

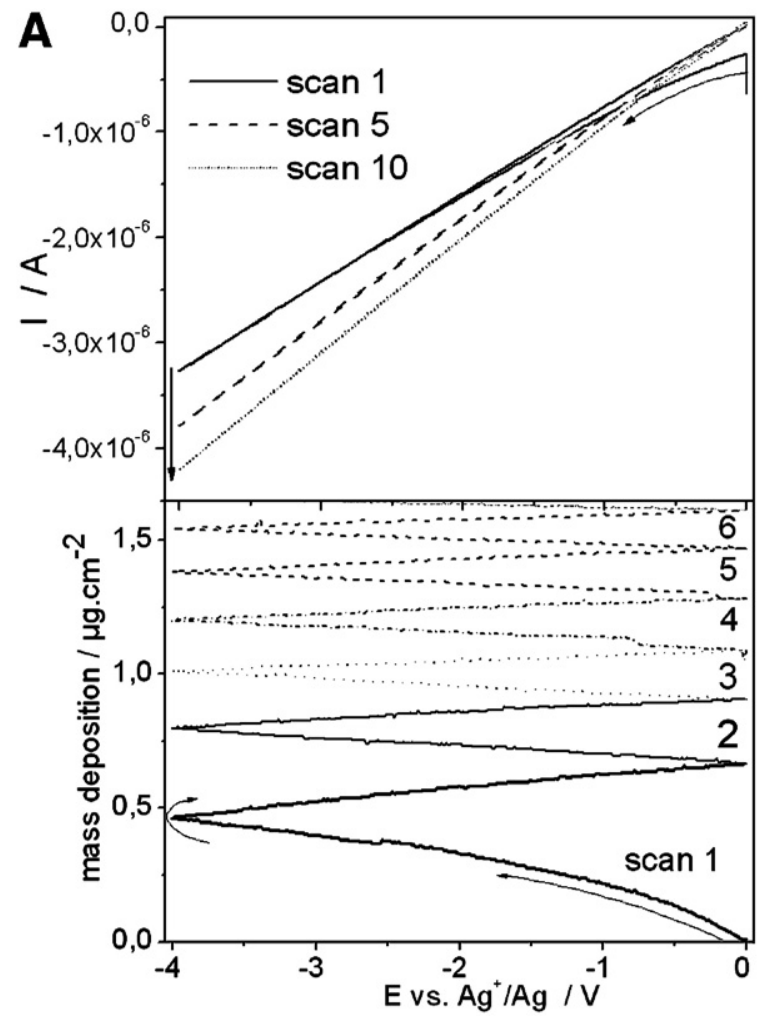

A Picoscan system (Molecular Imaging, USA) equipped with a $10 \times 10 \mathrm{~mm}^{2}$ scanner $(1 \mathrm{nA} / \mathrm{V}$ sensitivity) was used for STM measurements using $\mathrm{Pt}-\mathrm{Ir}$ tips prepared by electrochemical etching [11].

X-ray photoelectron spectroscopy (XPS) measurements were conducted on a ThermoElectron VG spectrometer equipped with a monochromatized $\mathrm{Mg} \mathrm{K} \alpha$ X-ray source (1486.6 eV photons) using pass energies of 150 and $20 \mathrm{eV}$ for survey and detailed scans, respectively. C1s peak of binding energy $(284.6 \mathrm{eV})$ was used as the reference.

SPR experiments were conducted on a Biacore 3000 (Biacore International AB, Uppsala, Sweden) using 3-APTES electrodeposited on bare gold sensor chip. After electrodeposition, the sensor chip was inserted in the Biacore device and a continuous flow of $10 \mathrm{mM}$ Hepes, $0.15 \mathrm{M} \mathrm{NaCl}, 3 \mathrm{mM}$ EDTA, $0.005 \%$ surfactant $\mathrm{P} 20, \mathrm{pH}=7.4$ (HBS-EP), over the sensor surface at $5 \mu \mathrm{L} / \mathrm{min}$, was maintained. All the following experiments were done at $25{ }^{\circ} \mathrm{C}$. First, the surface was rinsed with water and activated by injecting $300 \mu \mathrm{L}$ of glutaraldehyde $1 \%$. Then, after washing with water, $300 \mu \mathrm{L} \alpha$-lactalbumin at $2 \mathrm{mg} / \mathrm{mL}$ were injected on the surface.

\section{Results and discussion}

\subsection{Electrochemical modifications}

Initially we wished to use pure 3-APTES as solvent for electrolyte synthesis. But due to its low dielectric constant, it

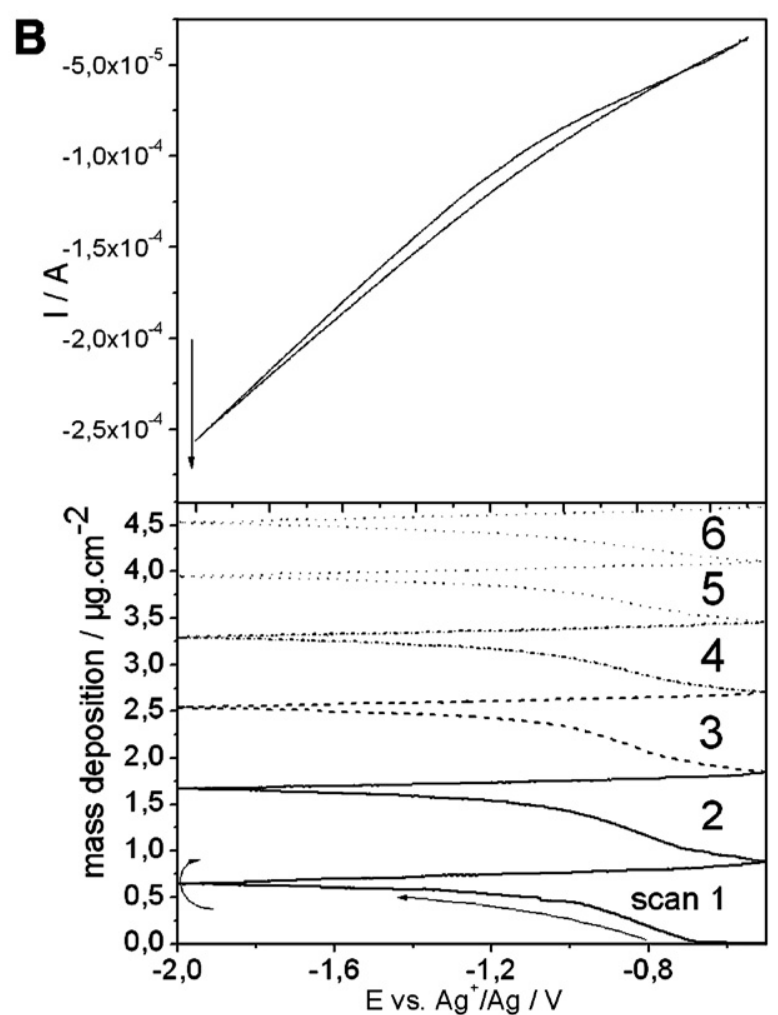

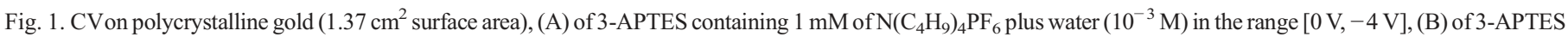
$\left(10^{-2} \mathrm{M}\right)$ plus water $\left(10^{-3} \mathrm{M}\right)$ in THF in the range $[0 \mathrm{~V},-2 \mathrm{~V}]$ at $20 \mathrm{mV} / \mathrm{S}$ and the simultaneous mass deposition as a function of the potential applied to a $5 \mathrm{MHz}$ gold coated AT cut quartz crystal. 
has never been regarded as a solvent of interest. Concerning salts, we had to avoid those containing alkali cations $\mathrm{M}^{+}$which could give the deposition of insoluble hydroxides when water is reduced $\left(\mathrm{M}^{+}\right.$salts yield insoluble $\mathrm{MOH}$ which coats and deeply modifies the interface). We used $\mathrm{N}\left(\mathrm{C}_{4} \mathrm{H}_{9}\right)_{4} \mathrm{PF}_{6}$ which is slightly soluble (notice that $\mathrm{LiPF}_{6}, \mathrm{LiBF}_{4}, \mathrm{LiSO}_{3} \mathrm{CF}_{3}, \mathrm{LiN}\left(\mathrm{SO}_{2} \mathrm{CF}_{3}\right)_{2}$ are insoluble). When the 3-APTES based electrolyte is saturated by this salt $\left(1 \mathrm{mM} \mathrm{NBu} \mathrm{PF}_{6}\right)$, its conductivity is low $\left(\kappa=0.03 \mu \mathrm{S} / \mathrm{cm}\right.$ at $\left.20^{\circ} \mathrm{C}\right)$, but it allows current-potential curves.
EQCM experiments coupled to cyclic voltammetry (CV) method were performed in 3-APTES charged with $10^{-3} \mathrm{M} \mathrm{N}$ $\left(\mathrm{C}_{4} \mathrm{H}_{9}\right)_{4} \mathrm{PF}_{6}$ in a wide potential window from 0 to $-4 \mathrm{~V}$. No mass variation and no faradic peak nor gas bubbling on the electrode surfaces (working and counter electrodes) has been observed. Then, in order to have similar conditions of the works already made on alkylsilanes [1-8] and evocated previously, we used 3APTES charged with $10^{-3} \mathrm{M} \mathrm{N}\left(\mathrm{C}_{4} \mathrm{H}_{9}\right)_{4} \mathrm{PF}_{6}$ plus freshly added water $\left(10^{-3} \mathrm{M}\right)$. The conductivity increased up to $\kappa=1 \mu \mathrm{S} / \mathrm{cm}$ at
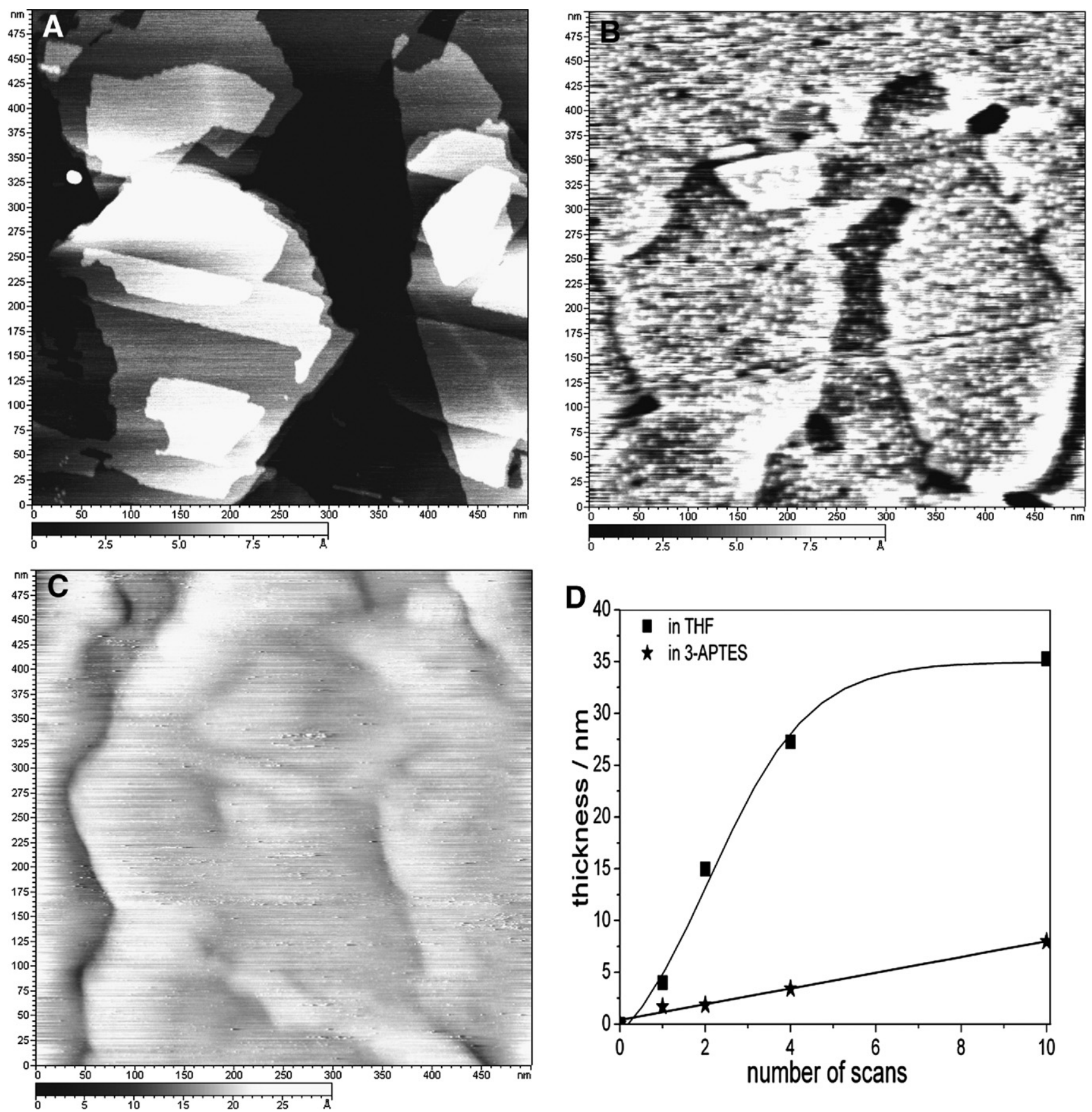

Fig. 2. STM pictures of: (A) freshly annealed $\mathrm{Au}(111)$ on mica $\left(10 \times 12 \mathrm{~mm}^{2}\right.$ surface area), (B) electrodeposited 3-APTES in THF between -0.5 and $-2 \mathrm{~V}$ during one scan and during 3 scans $(C)$ at $20 \mathrm{mV} / \mathrm{s}$. 3-APTES layer thickness as a function of the number of cyclic voltammetry scans (D) in either 3-APTES or THF based electrolyte by ellipsometry method. 
$20{ }^{\circ} \mathrm{C}$. The resulting electrochemical measurements in the range $[0 \mathrm{~V} ;-4 \mathrm{~V}]$ are gathered in the same Fig. 1A. The upper part concerns CV scans while the lower part is the gravimetric part. Both voltammograms and mass variation are plotted vs. potential. Although no reduction wave was observed even after 10 scans, there was an increase of current at the end of each cycle. In the same time, the mass deposition on gold electrode surface increased up to $2 \mathrm{mg} \mathrm{cm}^{-2}$ at the end of the 10th scan, according to the Lewis and Lu relationship implemented in the EQCM [12]. This corresponds to a frequency change of $115 \mathrm{~Hz}$ which is in excellent agreement with the $5 \mathrm{MHz}$ quartz crystal AT cut sensitivity of $56.6 \mathrm{~Hz} \cdot \mathrm{cm}^{2} \mathrm{mg}^{-1}$. Compared to anhydrous 3-APTES based electrolyte (charged only with $\mathrm{N}\left(\mathrm{C}_{4} \mathrm{H}_{9}\right)_{4} \mathrm{PF}_{6}$ ), there is a great influence of water traces: when the solvent is water free no deposition takes place, while when water is added, the deposition happens. Therefore, water presence is a key factor for the electrodeposition of 3-APTES on the metal surface. Water reduction yields hydroxyl ion formation on the surface electrode allowing then the hydrolysis and condensation of the 3-APTES.

In a second step, we wanted to examine the possibility to obtain well defined faradic peaks to elucidate the involved reactions by classical tests. So, we investigated further the electrodeposition of 3-APTES $10^{-2} \mathrm{M}$ (which corresponds to a 3-APTES:THF molar ratio of $1: 10^{6}$ ) in tetrahydrofurane (THF) because of its very negative cathodic limit, and a good solubility of siloxane and ammonium salt [13]. Although $\mathrm{N}\left(\mathrm{C}_{4} \mathrm{H}_{9}\right)_{4} \mathrm{PF}_{6}$ is very soluble, we kept its concentration to $1 \mathrm{mM}$ plus $1 \mathrm{mM} \mathrm{H}_{2} \mathrm{O}$ (pure THF $+1 \mathrm{mM}$ $\mathrm{N}\left(\mathrm{C}_{4} \mathrm{H}_{9}\right)_{4} \mathrm{PF}_{6}: \kappa=7.8 \mu \mathrm{S} / \mathrm{cm}$; pure $\mathrm{THF}+1 \mathrm{mM} \mathrm{N}\left(\mathrm{C}_{4} \mathrm{H}_{9}\right)_{4} \mathrm{PF}_{6}+$ $1 \mathrm{mM} \mathrm{H} \mathrm{H}_{2} \mathrm{O}: \kappa=9.5 \mu \mathrm{S} / \mathrm{cm}$ at $20{ }^{\circ} \mathrm{C}$ ) for working in the same conditions as 3-APTES charged with $\left.10^{-3} \mathrm{M} \mathrm{N}\left(\mathrm{C}_{4} \mathrm{H}_{9}\right)_{4} \mathrm{PF}_{6}\right)$. In addition: the resulting electrolytes are oxygen free. Consequently, only reduction of water takes place in the range $[0 \mathrm{~V} ;-2 \mathrm{~V}]$ as shown Fig. 1B. We observed on the lower part of this figure that the mass deposition occurs below $-0.7 \mathrm{~V}$. The electrogenerated hydroxide ions are only due to the water decomposition, acting as the catalyst for the hydrolysis and condensation of 3-APTES. Below $-1 \mathrm{~V}$ there is a slope change of the gravimetric curve and the mass deposition rate is optimum between $-0.7 \mathrm{~V}$ and $-1 \mathrm{~V}$. As there is no need to bias down to $-4 \mathrm{~V}$ as it was the case Fig. 1A, potential scans were limited in the potential range $[-0.5 \mathrm{~V} ;-2 \mathrm{~V}]$ in THF (with the same scan rate). At the end of the 6th scan, the mass deposition is more important than in pure 3-APTES electrolyte, reaching $4.7 \mathrm{mg} / \mathrm{cm}^{2}$. Clearly, 3-APTES has not to be concentrated in THF because the mass deposition is twice in THF based electrolyte than in pure 3-APTES one and water concentration has to be in the same range. Moreover, the deposition rate depends on the current which flows, consequently it depends on the conductivity. This can be related to the conductivity of THF charged with $1 \mathrm{mM} \mathrm{N}\left(\mathrm{C}_{4} \mathrm{H}_{9}\right)_{4} \mathrm{PF}_{6}$ and $1 \mathrm{mM}$ $\mathrm{H}_{2} \mathrm{O}$ which is ten time superior of that found in 3-APTES charged with $1 \mathrm{mM} \mathrm{N}\left(\mathrm{C}_{4} \mathrm{H}_{9}\right)_{4} \mathrm{PF}_{6}$ and $1 \mathrm{mM} \mathrm{H}_{2} \mathrm{O}$.

\subsection{Surface morphology and thickness of the samples}

After rinsing and drying the modified gold surfaces at ambient air, the deposited films give a slight and milky aspect to the gold surface. The topography of the 3-APTES thin film was examined Fig. 2 by STM after one and three $\mathrm{CV}$ scans of the electrodeposition process in THF as described previously. Fig. 2A shows a typical STM image of freshly annealed $\mathrm{Au}(111)$ substrate at air and illustrates the presence of atomically flat $\mathrm{Au}(111)$ terraces over hundreds of nanometers. Fig. 2B shows an image at air of the previous gold substrate, biased between -0.5 and $-2 \mathrm{~V}$ during one cycle at $20 \mathrm{mV} / \mathrm{s}$. 3-APTES nanoparticle growths (white spot with a diameter of about $5-10 \mathrm{~nm}$ ) took place with high coverage rate and were covalently bound on gold

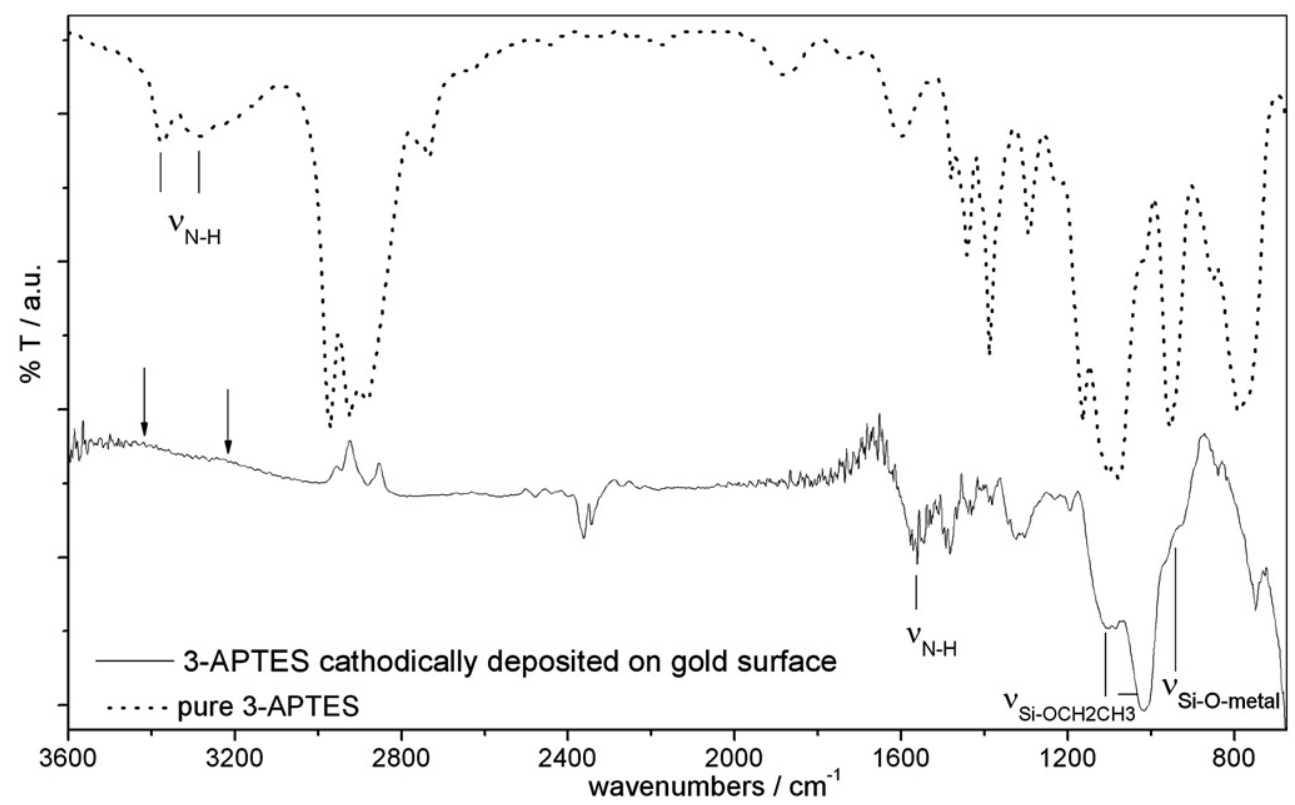

Fig. 3. IR-ATR spectra of pure 3-APTES (dot line) solution and electrodeposited 3-APTES on gold plated quartz crystal (solid line). 
via oxo bridges from hydroxyl groups that were electrogenerated on the whole electrode surface. At the end of the three CV scans (Fig. 2C), the gold substrate is uniformly passivated. The condensation of the hydrolyzed 3-APTES nanoparticles with the maximum degree of condensation happens on the surface in THF compared to 3-APTES based electrolyte. In fact, it is very difficult to image the 3-APTES film at this stage and impossible beyond three $\mathrm{CV}$ cycles because it becomes insulating. Moreover, one month after the surface modification, the coating does not crackle and flake off. Several reasons can explain this observation, i.e., the chemical bonding and the thickness of this film on gold that we will examine in the next three paragraphs.

The film thickness on the gold surface was measured by ellipsometric technique at air in a clean room. $\Psi$ and $\Delta$ values were then fitted using, as a model, a layer of amorphous silica on 3000 A-thick gold deposited on quartz crystal. The resulting thickness values (Fig. 2D), reported as a function of the $\mathrm{CV}$ cycle follow the same evolution as the mass deposition observed with EQCM measurements. On the other hand, there is a net difference between the mass deposition in THF and in 3-APTES for the same CV potential range $[-0.5 ;-2 \mathrm{~V}]$. Indeed, the thickness $v s$. the CV cycles in THF is best fitted with a sigmoid curve (square point plot), whereas in pure 3APTES a linear regression matches very well the experimental data (star point plot). Moreover, at the end of ten CV cycles the film thickness still increases either in THF or in 3-APTES but to a lesser extent than for the first cycles. The use of THF during the cathodic polarization process affects greatly the mass deposition compared to 3-APTES based electrolyte.

\subsection{Spectroscopic characterizations}

The chemical characterization was performed on the electrochemically modified gold coated quartz crystal in THF based electrolyte by IR-ATR spectroscopy (Fig. 3). The spectrum of pure 3-APTES (dot line) shows typical absorption bands at 3374 and $3282 \mathrm{~cm}^{-1}\left(v_{\mathrm{N}-\mathrm{H}}\right.$ for- $\left.\mathrm{NH}_{2}\right)$ also observed on silanized glass too [14]. The spectrum of the electromodified gold surface (solid line), quite different from the previous one enables us to detect$\mathrm{NH}_{2}$ groups despite the noisy band at about $1600 \mathrm{~cm}^{-1}$. It is possible to guess even the very weak but broad bands of the $-\mathrm{NH}_{2}$ stretching modes in the frequency range between 3200 and $3400 \mathrm{~cm}^{-1}$ (arrows on the Fig. 3) for electrodeposited 3-APTES. The strong doublet at 1104 and $1084 \mathrm{~cm}^{-1}$ as well as the stronger band at $1022 \mathrm{~cm}^{-1}$ give evidence of the $\mathrm{Si}-\mathrm{OCH}_{2} \mathrm{CH}_{3}$ presence. Between 1000 and $900 \mathrm{~cm}^{-1}$, shoulders at 972 and $930 \mathrm{~cm}^{-1}$ are in favor of the $\mathrm{Si}-\mathrm{O}-$ metal bonding $(\mathrm{Si}-\mathrm{O}-\mathrm{Au}$ stretching) and can be related to the good adhesion of the film on the gold surface [15].

Fig. 4 shows the XPS low resolution survey spectrum of the electrodeposited 3-APTES on gold before etching the surface. The $\mathrm{N} 1 \mathrm{~s}$ peaks at about $400 \mathrm{eV}$ correspond to the amino groups on the surface of the thin film and tend to vanish with etching time. This is a direct indication of 3-APTES grafting on gold surface via silano groups. In addition amino groups are present on the film surface. An enlargement towards $400 \mathrm{eV}$ shows two distinct peaks (Insert) after baseline correction and peak deconvolution. One at $399.7 \mathrm{eV}$ is typical of $-\mathrm{NH}_{2}$ while the other at higher $\mathrm{BE}(403 \mathrm{eV})$ is due to $-\mathrm{NH}_{3}^{+}$[16]. That can be put in relation with the results obtained in IR spectroscopy. The $-\mathrm{NH}_{2}$ groups belonging to the electrodeposited 3-APTES film have a protonated form explaining why there are two weak absorption bands beyond $3200 \mathrm{~cm}^{-1}$ compared to primary amine group of the pure 3-APTES. These two stretching vibrations have band intensities decreased to the profit of the bending mode (at about $1600 \mathrm{~cm}^{-1}$ ). It appears that the- $\mathrm{NH}_{2}$ (and $-\mathrm{NH}_{3}^{+}$) groups are engaged in intermolecular interactions and acid-base bonds respectively what reduces these stretching mode intensities.

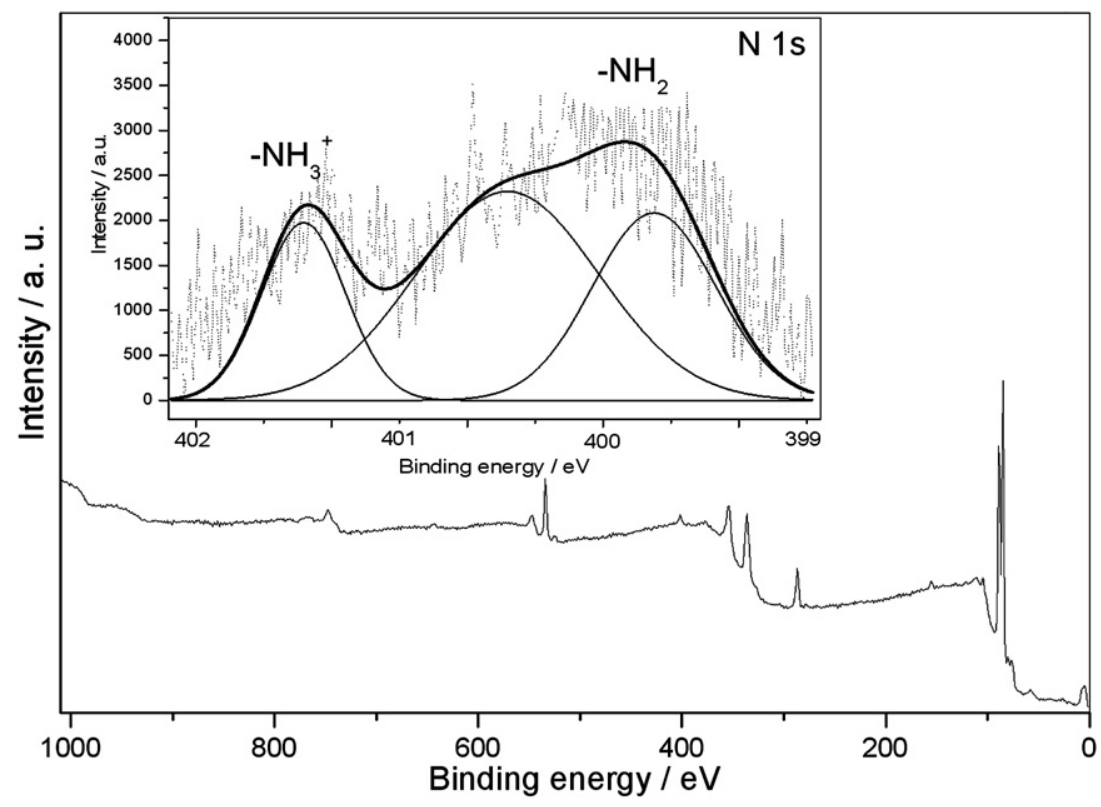

Fig. 4. XPS spectrum survey before surface etching and (inset) the N 1s peaks around $400 \mathrm{eV}$. 


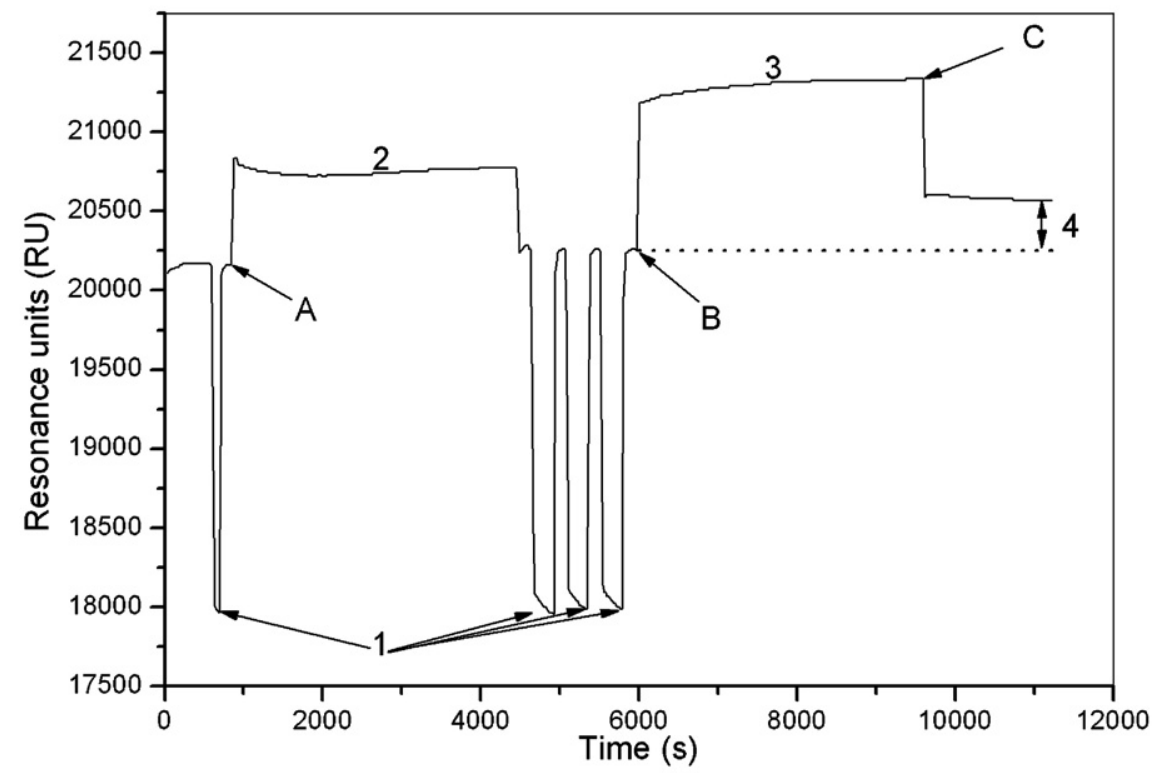

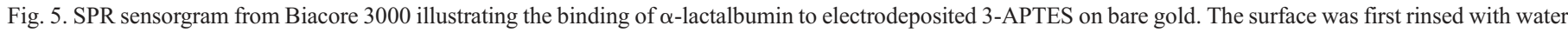

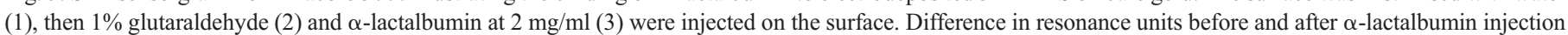
(4) corresponds to the amount of this protein covalently attached to the 3-APTES surface.

\subsection{Biosensor application}

The interest to obtain a surface covered with amino groups is to be able to graft in a covalent way thereafter biological molecules in mild conditions. Consequently, we followed the $\alpha$-lactalbumin graft on the 3-APTES film electrodeposited on a bare gold chip (corresponding to $2 \mathrm{CV}$ cycles deposition from the Fig. 2D) by means of the SPR shift (Fig. 5). After rinsing with distilled water (quoted 1 on the graph), 1\% glutaraldehyde was injected on the surface (arrow A) during 1400s (quoted 2). The sensor chip was rinsed three times with water (quoted 1) and $\alpha$-lactalbumin $(2 \mathrm{mg} / \mathrm{mL}$ ) was injected on the 3-APTES surface (arrow B) during 1700s (quoted 3). The injection of $\alpha$-lactalbumin is then stopped (arrow $C$ ) and the difference in resonance units before and after $\alpha$ lactalbumin injection corresponded to the amount of protein covalently attached to the 3-APTES surface (quoted 4). This result confirms that $-\mathrm{NH}_{2}$ groups on the top of the 3-APTES thin film are available for covalent binding of proteins. Furthermore, the electrodeposited 3-APTES thin film on gold surface for SPR experiments allows graft and detection of macromolecules such as $\alpha$-lactalbumin.

\section{Conclusion}

We have directly modified gold surfaces electrochemically with 3 -APTES when biased negatively below $-0.7 \mathrm{~V} / \mathrm{SRE}$. The resulting siloxane based film is not only grafted covalently to gold metal via oxo bridges but has also several tens of nanometers of thickness on gold surface suggesting a multilayer coating. Electrochemical studies of 3-APTES based electrolytes showed that gold surface modification is irreversible and mass deposition is larger in THF than in 3-APTES based electrolyte. More, depending on the electrode bias time, an accurate 3-APTES film thickness can be obtained making our finding attractive for biosensor applications.

\section{Acknowledgements}

This work was financially supported by a Grant-in-Aid for Scientific Research (RNTS 2003 No. 03 B 294) on allergy biochip from the Ministry of National Education and Research (MNESR).

\section{References}

[1] M. Okano, T. Toriumi, H. Hamano, Electrochim. Acta 44 (1999) 3475 and references therein.

[2] L.A. Vermeulen, K. Smith, J. Wang, 45, 1007 and references therein (1999).

[3] P.N. Deepa, M. Kanungo, G. Claycomb, P.M.A. Sherwood, M.M. Collinson, Anal. Chem. (2003) 5399.

[4] G. Herlem, K. Reybier, A. Trokourey, B. Fahys, J. Electrochem. Soc. 147 (2) (2000) 597.

[5] G. Herlem, patent PCT WOFR0101133 (2001).

[6] J. Diao, D. Ren, J.R. Engstrom, K.H. Lee, Anal. Biochem. 343 (2005) 322.

[7] S. Sayen, A. Walcarius, 5, 341 (2003) and A. Walcarius, E. Sibottier, Electroanal., 17, 1716 (2005).

[8] Z. Zhang, L. Nie, S. Yao, Talanta 69 (2006) 435.

[9] R. Shacham, D. Avnir, D. Mandler, Adv. Mater. 11 (1999) 384.

[10] H. Woo, P.J. Reucroft, R.J. Jacob, J. Adhes. Sci. Technol. (1993) 681.

[11] D. Barlow, L. Scudiero, K.W. Hipps, Ultramicroscopy 97 (2003) 47.

[12] O. Lewis, C. Lu, J. Appl. Phys. 43 (1972) 4385.

[13] H. Lund, M.M. Baizer (Eds.), Organic Electrochemistry: An Introduction and Guide, 3rd ed., Marcel Dekker Inc., ISBN: 0-8247-8154-6, 1991, p. 856.

[14] D. Beyer, W. Knoll, H. Ringsdorf, G. Elender, E. Sackmann, Thin Solid Films 284-285 (1996) 825.

[15] H. Schmidbaur, A. Shiotani, J. Am. Chem. Soc. 92 (1970).

[16] A.S. Maria Chong, X.S. Zhao, J. Phys. Chem., B 107 (2003) 12650. 